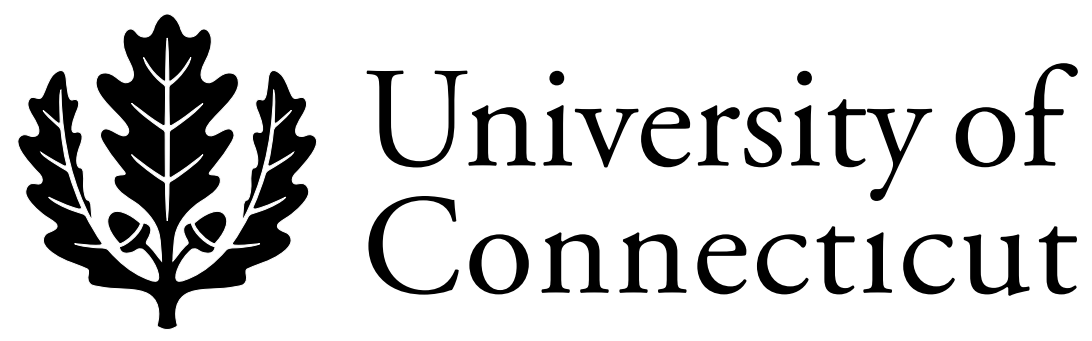

Department of Economics Working Paper Series

\title{
Productivity of a Commune: The Shakers, 1850-80
}

Metin M. Cosgel

University of Connecticut

John E. Murray

University of Toledo

Working Paper 1997-04R

November 1997

341 Mansfield Road, Unit 1063

Storrs, CT 06269-1063

Phone: (860) 486-3022

Fax: (860) 486-4463

http://www.econ.uconn.edu/

This working paper is indexed on RePEc, http://repec.org/ 


\begin{abstract}
How does the productivity of a commune compare with that of a conventional firm? This paper addresses this question quantitatively by focusing on the history of a religious commune called the United Society of Believers, better known as the Shakers. We utilize the information recorded in the enumeration schedules of the US Manufacturing and Agriculture Censuses, available for the period between 1850 to 1880 , to estimate the productivities of Shaker shops and farms. From the same data source, we also construct random samples of other shops and farms and estimate their productivities for comparison with the Shakers. Our results provide support to the contention that communes need not always suffer from reduced productivity. Shaker farms and shops generally performed just as productively as their neighbors; when differences did exist between their productivities, there are good reasons to attribute them to factors other than organizational form.
\end{abstract}




\section{Productivity of a Commune: The Shakers, 1850-80}

How does the productivity of a commune compare with that of a conventional firm?

Unlike a conventional firm, a commune distributes output to its members according to rules, such as equal sharing, that do not depend on members' effort. Because this independence between income and effort creates a potential for an incentive problem, those who emphasize the role of incentives on productivity would argue that, all else being equal, a conventional firm should be more productive than a commune. Those who consider the presumptions of the standard theory as being inapplicable to communes, on the other hand, would argue that work incentives in a commune, shaped by such things as communal work ethic and interdependence, are adequate to prove a commune to be just as productive, if not more, as a conventional firm.

These arguments about comparative productivity are ultimately quantitative, of course. But it is also very difficult to isolate and quantify the effect of organizational forms on productivity, because one needs to control for all other factors that might also be affecting productivity simultaneously. For example, one has to compare units that use similar inputs and produce similar products, or be able to control for the differences in the amounts and compositions of inputs and outputs. Difficulties of meeting such conditions might explain the discrepancies in the reported results of comparisons of alternative organizational forms ${ }^{1}$.

This paper aims to test quantitatively these arguments about the comparative performance of communes and conventional firms by focusing on the history of a religious commune called the United Society of Believers, better known as the Shakers. For this purpose, we use the information recorded in the enumeration schedules of the US Manufacturing and Agriculture Censuses available for the period between 1850 to 1880 . We first identify the Shaker entries in 
the schedules and then choose a random sample of other farms and manufacturing establishments for a comparison based on consistent data. Because the comparison sample is drawn from the schedules of the same townships as the Shakers, these neighboring farms and shops faced similar local constraints. We estimate the average productivities of the two groups of producers, identify and control for consistent non-organizational differences between them that might have affected effect their relative productivities, and assess the role of organizational differences.

\section{Communes and Their Productivity}

A commune is a collection of individuals who own property in common and whose personal shares of the gains from cooperative efforts are determined not by contribution to production but according to needs or by some other rule such as equal distribution of output among members. Members of a commune typically unite under a common ideology or a religious belief and seek to benefit from the joint pursuit of the prescribed goals. Some of the well-known examples of communes are the Hutterite colonies, the kibbutzim of Israel, and the historical American communities like the Shakers and the Amana Colonies.

Independence of income from effort in a commune appears to present a classic example of an incentive problem in production. Because the incremental revenue produced by additional effort is not directly reflected in a member's income, work incentives in a commune might be inadequate. Each member of the commune would have an incentive to choose suboptimal levels of effort and "free-ride" on the efforts of others. Suboptimal levels of effort by all members would then result in an inefficient level of total output produced by the commune. The standard

1. See, for example, the discussion in Bonin and Putterman (1987, p. 119-43). 
incentive theory would thus lead us to expect a commune to be less productive than comparable conventional firms that determine income directly from effort.

One might also argue, however, that the problem posed by the standard decision theory rests on certain presumptions about human motivation and interaction that are not necessarily true, at least not for communes. Two groups of factors have been argued to lead potentially to a different conclusion about comparative performance. The first is at the level of preferences. For example, as Sen (1966) argues, members of a commune might be altruistic, in which case each member's concern for the welfare of others would increase his or her incentives to work hard. Similarly, one might also argue that members of a commune may actually have a more positive attitude toward work itself. Because communes, unlike private firms, attract individuals to a strong ideology or religious belief which often views work as good or even as worship, a selfselection mechanism might ensure that only hard workers join the commune ${ }^{2}$. The possibility of such preferences would imply that communes need not have an incentive problem and produce inefficiently.

The second group of factors affect incentives through social interaction, even under the conventional assumptions about preferences. For example, as Putterman (1983) argues, even self-interested behavior can actually result in an equilibrium of high incentives in a commune if the effort decisions of members are interdependent (contrary to independence typically assumed in the standard incentive theory). That is, if one's choice of effort strategically considers its effect on the effort choices of others, then it might be individually and socially optimal to establish a norm of hard work within the commune. Similarly, peer pressure and various social factors such as shame,

2. But self-selection can also work in the opposite direction if the commune does not or cannot carefully scrutinize the actual intentions of potential entrants. That is, individuals might join not for ideological or religious reasons but simply to improve their living standards. See Murray(1995). 
guilt, and mutual monitoring might interact to create internal incentives to work hard in a commune ${ }^{3}$.

Going beyond the standard incentive theory, one can thus find reasons to expect communes to be just as productive as conventional firms. Which, then, is the more correct view of the productivity of a commune: less productive than others as implied by the standard theory, or equally productive as implied by alternative approaches? The issue is ultimately quantitative. It can only be determined by measuring the productivities of specific communes and by comparing them with the productivities of comparable conventional firms.

There are surprisingly few systematic studies that address quantitatively the comparative productivity of communes and conventional firms. An ideal quantitative comparison requires isolating conventional firms that are identical, or at least similar, to communes in all nonorganizational respects. It also requires reliable and consistent (e.g., same variables, based on the same recording conventions) data for both the communes and the comparable units. Data limitations make such an ideal comparison very difficult. Therefore, quantitative studies of productivity tend to use data sets that consist of only communes and either make no comparisons with conventional firms or estimate the productivity of a particular commune and then compare it with the productivity estimate of some aggregate of conventional firms often available from another source. As an example of the first, Putterman (1990) examines the role of material incentives on effort and productivity in a 1970s Chinese People's commune. As an example of the second, Barkai (1977: 123-37) estimates the total factor productivity of kibbutz production

3. See Kandel and Lazear (1992) for a discussion of these issues in the context of partnerships and Weitzman and Kruse (1990) in the context of worker-management and profit-sharing programs, which are also applicable to communes. Elinor Ostrom and others find that common property arrangements work best for small, relatively homogenous groups who share similar beliefs and objectives. See Ostrom (1990) and Keohane and Ostrom (1995). See also Roehl (1972) for a case study of the effects of religious ideology on labor effort. 
branches and compares the result with the same measure for the comparable sectors of the Israeli economy. He argues that "we may say that kibbutzim did no worse in terms of productivity gains than the Israeli private non-dwelling economy as a whole, and very probably did better."(Barkai 1977: 136) This conclusion does not seem very convincing, however, because it is based on different types of data and an insufficiently particular comparison. Such a comparison is too general to control for many of the factors, such as size, products, and market conditions, that might have also affected productivities ${ }^{4}$. A more convincing study must isolate comparable conventional firms, use data from the same source, and control for non-organizational differences.

This paper aims to fulfill this task by focusing on the Shakers. We estimate the productivities of farms and manufacturing enterprises in Shaker communes and compare them with the productivities of a random sample of other farmers and manufacturers in the same areas. For both the Shakers and others, we use the same source of information: the US Census enumeration schedules. Census information also allows us to examine the role of other differences that might have affected productivity.

\section{The Shakers and Observations on Their Productivity}

As a Christian communal society, the Shakers were well-known for their commitments to celibacy, common property, and communal distribution of output (Stein 1992). By the year 1800, they numbered 1373 and maintained eleven communities in New York and New England (Brewer 1986). In 1850, US Census recorded the greatest number of Shakers, when 3842 members lived in twenty one communities located between Maine and Kentucky (Bainbridge 1982).

4. Similar problems exist in the empirical studies of comparative productivity concerning other organizational forms. See Bonin, et al (1993: 1302-07) for a review of these difficulties in the literature on producer cooperatives. 
Shaker communalism evolved gradually. The Shakers of the late 1770 s and early 1780 s retained their privately owned property after joining. Communalism was initiated in the winter of 1782-1783: "The time is come to give up yourselves and your all to God--your substance, your temporal property--to possess as though you possessed not. We shall have one meeting together," wrote James Whittaker, a prominent Elder (Andrews 1963: 48). The first community covenant of 1795 called for members to give all their worldly property to the "Joint interest of the Church," in which "all should have Just and Equal rights and Privileges, according to their needs...without Any difference being made on account of what any of us brought in." (Andrews 1963: 62).

Each Shaker community consisted of several semi-autonomous subdivisions of communes, called "families," units ranging in size from about ten to more than one hundred persons ${ }^{5}$. The basic unit of social interaction for each Shaker was the family commune, which was also the basic economic unit. Each commune typically developed a mixed economy of agricultural production and several manufacturing enterprises. Some Shaker products, especially chairs, garden seeds, brooms and brushes, and medicinal herbs and roots, became well-known nationally.

How representative is Shaker communalism in addressing the general relationship between work-incentives and economic productivity in communes? It is true that the Shaker communes were different from Soviet, Chinese, or Yugoslavian operations in terms of, for example, size, governance, economic structure, and religious and political ideology. What is more relevant here, however, is the fundamental similarity in the way all communes typically compensate labor (creating the potential for incentive problem) and seek to unite members under a common 
ideology (creating the potential for high effort). Although the relative importance of these two potentials might vary among communes (possibly caused by their differences in terms of size, governance, and so on), we see this variation as outweighed by the more fundamental difference between all communes and all conventional firms. The focus on the Shakers provides an adequate framework to address whether communes can be as efficient as conventional firms, or to test whether the arguments of the standard incentive theory or of alternative approaches to human motivation are more accurate.

The argument of the standard incentive theory is applicable to the Shakers in that the return to labor was independent of effort. In each Shaker family, all members worked together in communal farms and shops. In return, they had "a just and equal right to the use of things, according to their order and needs". (Father Joseph, quoted in Andrews 1963: 62) Thus, rather than a wage income for labor, they earned the right to consume communal goods, a right which depended neither on one's ability to work nor on actual effort. As Stein (1992: 149) puts it, "[t]hey ate at the same tables, shared living quarters, slept in the same rooms..., and used the same sanitary facilities." Because of the independence of effort and income, standard incentive theory would thus predict the Shakers farms and shops to be less productive than other conventional ones.

The argument of alternative approaches to human motivation is also applicable in that Shakers principles placed a high value on labor. An early Shaker didactic formula, attributed to their foundress, Mother Ann Lee, urged: "Put your hands to work and your hearts to God." Correspondence and journals of the Shakers provide numerous examples of the importance of this principle in shaping the Shaker attitude toward work (Gooden 1983; Andrews 1963: 94-135).

5. For an analysis of the Shaker family system, see Coşgel, Miceli, and Murray (1997). 
For example, an excerpt from a Shaker writing in 1816 stated: "our labor is to do good, in our day and generation, to all men, as far as we are able, by faithfulness and frugality in the works of our hands." Alternative approaches would thus predict the Shakers to be just as productive as others, and perhaps even more productive.

The question then becomes whether the Shaker attitude toward work was strong enough to dominate the incentive problem in the way it affected the performance of their economic enterprises. On this issue, observers and historians of the Shakers have almost unanimously praised the Shaker economy as being very successful, in both manufacturing and agriculture ${ }^{7}$. Richard T. Ely, a founder of the American Economic Association, visited the Shakers in 1885 and wrote: "Economically, the Shakers have been a complete success" (Ely, 1886: 12). Reviewing the written comments of the contemporary observers of the Shakers, Andrews (1974: 190) notes that "the observations of the visitors on the economy of the [Shakers]...were with few exceptions favorable and often laudatory" (Emphasis original). Observations on the comparative performance of the Shakers were equally favorable. As Andrews reports, "compar[ing] their condition with that obtaining among contemporary mechanics and agriculturists in the world...most observers...passed judgments highly favorable to the [Shakers]." 8

Are these observations, especially on comparative performance, accurate and justified? Although both the general observations and the comparisons of the Shakers with others might be somewhat reliable in that they are based on first hand observations of the contemporaries, they are

6. Shaker Memorial, 1816, quoted by Andrews (1963: 94).

7. For an example to the contrary, see Stein (1992: 135-48), who examines the economics of the community during the middle period (1827-1875) and finds mixed results: expanding prosperity at first, but eventual difficulties in the latter part of this period as the Shakers increasingly entered "the world of finance capitalism". 8. Andrews (1974: 194). Emphasis original. For examples of such comments, see pp. 194-7. See also Nordhoff (1875: 390) for a similar comparison, based on his personal observations, of the Shakers with other American communes. 
not based on a systematic and quantitative study. Particularly the comparative comments should be taken as only tentative because they suggest a quantitative difference in performance without actually providing quantitative support. Quantitative information about the Shakers and others to allow such support was not available, of course, to Ely and other contemporary observers of the Shakers at the time. Census records make it possible now.

\section{Were the Shakers Equally Productive?}

The sources of data for this study are the enumeration schedules of the federal censuses of population, agriculture, and manufacturing for $1850,1860,1870$, and 1880 . We first identified all entries for the Shakers recorded in the agriculture and manufacturing schedules. Where possible (i.e., if the families were recorded separately), we used the Shaker family as the unit of analysis; where we could not find family-level data, we used the entire community as the unit. The Shakers were sometimes easy to identify in the schedules when they were recorded simply as, for example, "Church Family of Shakers." But sometimes the enumerators entered the information about the Shakers under the name of one of the Shakers, usually a trustee. In that case, we relied on our knowledge of Shaker leadership (based on secondary sources and the Shakers' own manuscripts) and also on the names of the Shakers recorded in the population schedules. In addition to identifying the Shakers, we constructed random samples of other producers (by randomly selecting five entries from each township in which the Shakers were recorded in the schedules) for each of the agriculture and manufacturing censuses for comparison with the Shakers ${ }^{9}$. We were

9. Such a comparison sample makes it possible work with firm-level data, rather than rely solely on the (often inaccurate) summary information published by the U. S. Census Bureau. See the Appendix for a discussion of the way the neighboring farms and shops can represent other conventional producers in the surrounding counties. 
thus able to gather consistent data about the agricultural and manufacturing operations of both the Shakers and comparable conventional producers.

Both the manufacturing and agriculture schedules include detailed information about inputs and outputs, making it possible to calculate different measures of productivity. Manufacturing schedules show the value of capital investment and the quantities and values of raw materials, labor, and products, making it possible to calculate both the total revenue and the total cost of production and to use their ratio as a simple measure of total productivity in manufacturing $^{10}$. We also calculate the value added per worker and average revenue of raw materials as measures of the partial productivities of labor and material inputs.

Agriculture schedules similarly provide information about inputs and outputs, but the information is not very detailed before 1870 . On the cost side, the schedules for 1850 and 1860 provide only the values of farms, farming implements and machinery, and livestock. The estimate of total cost is thus restricted to the user cost of capital only, which would make the comparisons of total productivity less reliable if the proportion of omitted items to those included is not identical between Shaker farms and others. On the revenue side, the schedules provide only earnings generated from orchard products, market gardens, home manufactures, and animals slaughtered (or sold for slaughter). The revenue of other products thus need to be estimated by using market prices and the reported quantities that each farm produced ${ }^{11}$. Agriculture censuses of 1870 and 1880 provide more information. For example, in both years farmers reported the "estimated value of all farm productions (sold, consumed, or on hand)." Furthermore,

10. Federal Government Bond yield for 1850 and Railroad Bond yields for 1860-80, as reported in Homer and Sylla (1991: 287-88), are used as the rate of interest in calculating the user cost of capital.

11. 1860 prices are from Atack and Bateman (1987: 232-7). For 1850, reliable prices are available for New York and Cincinnati, as reported in Ronk (1936) and Berry (1943). New York prices are used as proxies for prices in 
information about cost included the wages paid (for both 1870 and 1880), the cost of building and repairing fences (for 1880 only), and the cost of fertilizers purchased (for 1880 only).

Similar to the estimation of productivity in manufacturing, we use the ratio of revenue to cost as the measure of total productivity in agriculture. Because the agricultural schedules do not provide information about the quantity of labor, however, we cannot estimate its partial productivity in agriculture. The schedules nevertheless provide information about the quantity of land, allowing for an estimate of the partial productivity of land (calculated as the ratio of total revenue to the acres of improved land).

One might question the reliability of census data to estimate the productivity of the Shakers because of the potential biases generated by the peculiarities of communal organizations. That the Shakers owned assets jointly and received non-monetary remuneration for their labor raises several questions about the accuracy of some of the entries in the census schedules and thus about the reliability of the estimates of their productivity. For example, because the Shakers owned assets in common and because by the 1850s they had owned the farms for a long time, could it be that they did not know the current full market value of their land or that, even if they knew the market value, they underreported it? Similarly, because the Shakers did not receive direct monetary payments for their communal labor, could it be that the quantities of labor recorded in manufacturing schedules refer only to hired hands or that, even if the quantities refer to the Shakers, the census schedules failed to record the cost of their labor accurately? In such cases, estimates of Shaker productivity would be biased, and the comparisons of their productivity with those of other farmers would be misleading.

the eastern states included in this study (Maine, Massachusetts, New York, Connecticut, New Hampshire), and Cincinnati prices for western states (Ohio, Kentucky). 
As we discuss in more detail in the Appendix, the tests we performed to address these issues suggest that the census entries for the Shakers about the values of their land and the quantities and cost of their labor are not significantly biased. We find that the average value of land was not significantly different between the Shaker farms and others. We also believe that the quantity of labor and wage figures enumerated for the Shakers reported, first, the number of Shakers who worked in a particular shop and the hours they worked, and second, the enumerators' estimates of what these Shakers would have been paid for the same work had they been hired hands. We thus believe that the productivity estimates for the Shakers are not significantly biased.

Table 1 reports the measures of manufacturing productivity per establishment and agricultural productivity per farm, separately for the Shakers and other producers ${ }^{12}$. In manufacturing, there are no statistically significant differences (at conventional levels) between the averages of the Shakers and other manufacturers in terms of either total productivity or the partial productivities of labor and material inputs. In agriculture, however, comparisons of average productivity yield mixed results. Whereas the average revenue of land was significantly greater on Shaker farms in 1850 and there were no significant differences in average total productivity between the two groups of farmers in 1850 and 1860, the Shaker farms were less productive in 1870 and 1880.

\section{Determinants of Agricultural Productivity: What Caused the Difference in 1870 and 1880 ?}

12. The decline in the revenue/cost ratios in agriculture for both groups of farmers after 1870 reflect both additional items added to cost and the different methods of calculating revenue. The decline in some of the agricultural and manufacturing productivity measures between 1870 and 1880 may be attributed to the falling prices of products between the two census years. There are no consistently significant regional variations (in absolute or relative terms) in productivity among different regions. 
Two main conclusions emerge from the comparisons of productivities between the Shakers and other producers. The first is that on average the Shaker manufacturing enterprises were just as productive as the conventional ones. The second, however, is that, whereas the Shaker farms were equally (or more) productive as the conventional ones in 1850 and 1860, they were less productive in 1870 and 1880 . The question then becomes whether it was the difference in organizational form or something else that caused the difference in agricultural productivity in 1870 and 1880. That is, rather than the organizational form, could it be other systematic differences between the Shaker farms and others, for example in terms of the amounts and compositions of inputs and outputs, that caused the observed differential in the revenue/cost ratios during this period. We thus need to identify significant non-organizational differences between the Shaker farms and others and determine their effect on productivity.

In terms of inputs, because the Shakers operated farms primarily to meet the food needs of large numbers of members, one would expect these farms to be larger in size than others. Indeed, as Table 2 shows, the amounts of both total land and capital investment (values of farm, implements and machinery, and livestock) were much larger on Shaker farms than on others. In terms of outputs, because the Shakers operated large communal farms that were more likely to be engaged in subsistence agriculture, one would expect both the variety and the composition of products to be different between the two types of farms. As Table 2 shows, the Shakers consistently produced a significantly greater number of products and a higher ratio of perishables than other farms, confirming the expectation ${ }^{13}$.

13. Ratio of perishables is the share of income that came from butter, cheese, garden products, and orchard products (as a percentage of income from 13 products--for consistency across censuses--that also includes wheat, corn, rye, oats, potatoes, hay, peas and beans, wool, and animals slaughtered). 
What effect did these differences between the Shaker farms and others have on their relative productivities? To identify the determinants of agricultural productivity, we tested for the effects on total productivity (revenue/cost ratio) of the amount of capital investment (values of farm, implements and machinery, and livestock), capital intensity (capital/land ratio), number of products, and ratio of perishables. We also used a dummy variable (Shaker farms $=1$, others $=0$ ) to test for the difference between the Shakers and others in the way each variable affected their productivity. By interacting each variable through its multiplication with the dummy variable, we created new variables that would help us determine whether the effect of each variable was felt differently by the Shaker farms and others. Because tests for heteroscedasticity showed that error variances were highly correlated with capital, we corrected for the problem by transforming variables (divide by capital) and estimating the transformed regression equation.

Table 3 shows the results of the weighted least-squares procedure, reported in terms of the coefficients corresponding to original variables. The coefficients of dummy-transformed variables are generally insignificant, except for ShakerxCapital which is significant at the $11 \%$ level in 1850 and 1860 and less significant in 1870 and 1880. The coefficients of non-interacted terms are generally significant (though with exceptions) at conventional levels, and their signs are consistent across the four censuses. On the input side, the negative signs of capital and capital/land ratio suggest that additional capital investment and capital intensity contributed more to (capital) cost than to revenue ${ }^{14}$. The positive sign (though less significant) of the differential effect of capital (ShakerxCapital), however, suggests that the negative effect of capital was offset to a degree on Shaker farms. On the output side, the positive sign of the number of products shows economies of scope in the way increased variety of products had a positive effect on 
agricultural productivity. Higher ratio of perishables, on the other hand, had a negative effect.

One explanation could be that perishables might have been too labor-intensive and therefore contributed at the margin a below average amount to the farm's income.

Although the regression results do not change much over the four regressions (except for the reduced significance of capital/land ratio in 1870 and ratio of perishables in 1880), combined with the known systematic differences between the two types of farms, they provide an explanation of the change in comparative productivity after 1870 . There are two noteworthy systematic changes between $1850 / 60$ and $1870 / 80$, both having to do with capital. The first is that the capital differential between the Shaker farms and others increases significantly after 1870 , suggesting that the Shakers felt the negative effect of capital even more so during this period. As seen in Table 2, the amount of Shaker capital grew significantly both relative to the earlier period and relative to their neighbors (from about 6 or 7 times greater in 1850/60 to about 9 or 10 times greater in the later period). Because of the significant and negative effect of capital on productivity, the Shaker farms thus suffered proportionally much greater after $1870 .{ }^{15}$ The second is that the interaction term of capital for the Shakers (Shaker x Capital), though not very significant, becomes even less significant after 1870. This suggests that, whereas the Shakers were able to offset to a degree the overall negative effect of capital during 1850 and 1860, the advantage vanished in 1870 and $1880^{16}$.

14. The negative coefficients for capital variables are puzzling, but it is beyond the scope of this paper to address. 15. Note also that the argument about the central role of capital in causing the productivity differential in 1870 and 1880 is consistent with the similarity in the partial productivity of land between the two groups during the same period. Average revenue of land, a measure that does not include the cost of capital, is greater for the Shakers in 1850 and about the same between the two groups thereafter, suggesting that differences in total productivity reflect the role of capital.

16. Another significant change in the Shaker history of this period, which cannot be directly incorporated into our quantitative analysis, is the sharp fall in Shaker membership and a change in its composition toward more females and elderly (Bainbridge 1982, Brewer 1986). The Shakers thus had to hire large numbers of workers from outside to meet seasonal labor needs on farms, which probably had a negative effect on the productivities of Shaker farms. 


\section{Conclusion}

Information contained in the enumeration schedules of the U. S. Agriculture and Manufacturing Censuses provides an excellent opportunity to estimate the productivities of the Shakers and to compare them with other producers randomly drawn from the same source of data. Our results show that the Shaker farms and shops generally performed just as productively as other producers, with the exception of significantly lower Shaker total productivity in agriculture in 1870 and 1880. Identifying and controlling for non-organizational differences between the two groups of farmers, we argue that the productivity difference in 1870 and 1880 can be attributed to the changing role of capital rather than differences in organizational form.

Our narrow focus on the Shakers and their neighbors has wider implications about the comparative productivities of communes and conventional producers. Using economic history to clarify and test contemporary economic theory, we argue that, all else being equal, a communal enterprise can be just as productive as a conventional one. Although a communal enterprise behaves differently in the way it distributes output to its members, this need not have an adverse effect on its productivity. Other unique features of a commune, such as unconventional preferences or work attitudes of its members and the interdependence of their decisions, can help to overcome the potential for reduced incentives to work hard.

\footnotetext{
Any potential for incentive problems applied equally to the hired hands (who were paid a daily wage and whose individual contributions to output could not be costlessly observed in team production), and the hired hands did not share any commitment to Shaker goals or have any other stake in Shaker Society. See Nordhoff (1875) for the numbers of hired hands, as of mid-1870s, in different communities.
} 


\section{Appendix}

Discussion of the potential problems of using census data to estimate the productivities of the Shakers and to compare with their neighbors:

a. Did the Shakers value their farms correctly?

As Table 2 shows, there are no consistent and significant differences between Shaker farms and others in terms of average land values, measured as the ratio of farm value to total (improved + unimproved) land.

b. Could the quantity of labor recorded in census schedules refer to hired hands only?

As Table 2 shows, the capital/labor ratios in Shaker shops are not significantly different from those in conventional firms. If the labor figures referred only to hired hands, we would have observed significantly higher ratios of capital to labor. Moreover, writers on the Shakers frequently comment on the many unskilled hired hands in agriculture but not in manufacturing.

c. How are men and women counted in the calculation of value added per worker?

Men and women (and children in 1870 and 1880) are counted as equals in labor inputs. This could potentially bias the comparison if the labor input between men and women and their ratios between the two groups were both significantly different. Although the Shaker shops in general had a higher ratio of female workers, the differences are not significant enough to affect the results.

d. Does the fact that the Shakers did not actually receive money wages significantly bias the results?

The existence of information about both the quantity and cost of labor in the manufacturing schedules suggests that for census purposes the Shakers provided an estimate of the cost of their labor (possibly with the assistance of the enumerator who was presumably 
knowledgeable about the going wage rates in the area). We tested for the accuracy of these entries by using the average wages paid by other firms in each township and recalculating the cost of labor in Shaker shops in the same township (that is, by multiplying these figures with the quantities of labor recorded for Shaker shops). This procedure is possible only for 1850 and 1860, because the 1870 and 1880 Censuses do not report the average monthly wages of males and females separately. By including the recalculated cost of labor in the total cost of Shaker shops, we reach new revenue/cost ratios for the Shakers for 1850 and 1860: 1.33 and 1.23 (the new $\boldsymbol{t}$-statistics that test for the significance of their difference from the averages of other producers are 0.33 and 0.67 ). The difference between the new estimates for the Shakers and the average ratios of non-Shaker shops still remains insignificant.

\section{e. Does the exclusion of supervisory labor bias the results?}

Census schedules do not provide separate information about the proprietor or the salaried managers, and there are good reasons to believe that such labor was not included in the labor figures (Atack 1985: 76-78 and Bateman and Weiss 1981: 109-13). This would underestimate the total labor cost and bias the revenue/cost ratios especially in small firms where the supervisory cost can represent a significant portion of the total. In order to test for this possibility, we used a procedure similar to that employed by Bateman and Weiss (1981: 109) by restricting the comparison of productivities in 1850 and 1860 (during which the Shaker shops were significantly smaller) to those firms with capital worth over $\$ 2,000$. In 1850 , there were 34 such Shaker firms with an average revenue/cost ratio of 1.19 and 49 other firms with 1.30. In 1860, 18 large Shaker firms averaged 1.16 and 33 other firms 1.30. The $t$-statistic to test for the difference between the averages of the Shaker and other firms were 1.14 in 1850 and 0.98 in 1860 . Although there is thus a more noticeable difference between the productivities of the Shaker and other firms (as 
compared to the original revenue/cost ratios reported in Table 1), the difference is still statistically insignificant at conventional levels.

\section{f. How representative is the comparison sample of neighboring farms and shops?}

To determine the representativeness of the firms in the comparison samples and at the same time to control for local factors, we used published census summaries for each of the seventeen counties (in seven states) that include Shaker communes. We calculated the countylevel values of the variables reported in Table 2 and the values of the $t$-statistics that test for the significance of the differences between the averages of the counties and the comparison samples (available upon request), which show no significant differences at conventional levels for any of the variables. 
TABLE 1

Comparison of Average Productivity, Shakers and Others

\begin{tabular}{|c|c|c|c|c|c|}
\hline \multirow{2}{*}{\multicolumn{6}{|c|}{ MANUFACTURING }} \\
\hline & & & & & \\
\hline \multicolumn{6}{|c|}{ Revenue/Cost Ratio } \\
\hline & Shakers & 1.35 & 1.26 & 1.62 & 1.61 \\
\hline & Others & $\begin{array}{c}1.36 \\
(0.10)\end{array}$ & $\begin{array}{c}1.34 \\
(0.51)\end{array}$ & $\begin{array}{c}1.56 \\
(0.33)\end{array}$ & $\begin{array}{c}1.59 \\
(0.16)\end{array}$ \\
\hline \multicolumn{6}{|c|}{$\begin{array}{l}\text { Value Added per Worker } \\
\text { (\$/Worker) }\end{array}$} \\
\hline & Shakers & 523.6 & 672.1 & 1384.4 & 883.8 \\
\hline & Others & $\begin{array}{c}563.2 \\
(0.57)\end{array}$ & $\begin{array}{l}695.1 \\
(0.12)\end{array}$ & $\begin{array}{c}1539.5 \\
(0.30)\end{array}$ & $\begin{array}{l}841.4 \\
(0.18)\end{array}$ \\
\hline \multicolumn{6}{|c|}{ Average Revenue of Raw Materials (Output/Input) } \\
\hline & Shakers & 2.68 & 3.67 & 2.53 & 2.66 \\
\hline & Others & $\begin{array}{l}2.91 \\
(0.71)\end{array}$ & $\begin{array}{l}3.63 \\
(0.03)\end{array}$ & $\begin{array}{l}2.91 \\
(0.79)\end{array}$ & $\begin{array}{c}2.50 \\
(0.47)\end{array}$ \\
\hline
\end{tabular}

Sample Size

$\begin{array}{lllll}\text { Shakers } & 64 & 48 & 32 & 46 \\ \text { Others } & 70 & 42 & 40 & 60\end{array}$

AGRICULTURE

Revenue/Cost Ratio

$\begin{array}{lcccc}\text { Shakers } & 3.42 & 3.41 & 1.79 & 1.24 \\ \text { Others } & 3.43 & 3.05 & 2.53 & 2.72 \\ & (0.01) & (0.94) & (2.73) & (4.81)\end{array}$

Average Revenue of Land (\$/Improved Acres)

$\begin{array}{lcccc}\text { Shakers } & 12.70 & 13.95 & 15.06 & 11.35 \\ \text { Others } & 8.22 & 11.66 & 15.91 & 11.62 \\ & (3.34) & (1.17) & (0.49) & (0.15)\end{array}$

Sample Size

$\begin{array}{lllll}\text { Shakers } & 42 & 38 & 36 & 34 \\ \text { Others } & 80 & 75 & 70 & 65\end{array}$

Notes: See text for an explanation of the calculation of cost and revenue.

Figures in parentheses are the $\boldsymbol{t}$-statistics that test for the difference between the two means. Sources: U.S. Bureau of the Census, Enumeration Schedules of the Agriculture and

Manufacturing Censuses, 1850-1880. 
TABLE 2

Differences between the Averages of the Shakers and Other Producers

\begin{tabular}{|c|c|c|c|c|}
\hline & 1850 & 1860 & 1870 & 1880 \\
\hline \multicolumn{5}{|l|}{ MANUFACTURING } \\
\hline \multicolumn{5}{|l|}{ Capital (\$) } \\
\hline Shakers & 1431.6 & 2148.6 & 3524.5 & 2956.4 \\
\hline Others & $\begin{array}{c}4221.4 \\
(2.23)\end{array}$ & $\begin{array}{c}3880.1 \\
(1.87)\end{array}$ & $\begin{array}{c}3871.9 \\
(0.23)\end{array}$ & $\begin{array}{c}2790.0 \\
(0.14)\end{array}$ \\
\hline \multicolumn{5}{|l|}{ Capital / Labor Ratio (\$ / worker) } \\
\hline Shakers & 576.6 & 914.8 & 1445.0 & 580.9 \\
\hline Others & $\begin{array}{l}753.7 \\
(1.44)\end{array}$ & $\begin{array}{c}664.9 \\
(1.06)\end{array}$ & $\begin{array}{c}846.7 \\
(1.34)\end{array}$ & $\begin{array}{c}866.8 \\
(1.71)\end{array}$ \\
\hline
\end{tabular}

\section{AGRICULTURE}

Total Land (Improved + Unimproved Acres)

$\begin{array}{lcccc}\text { Shakers } & 870.3 & 1321.3 & 1148.5 & 1024.1 \\ \text { Others } & 174.0 & 136.7 & 119.8 & 101.8 \\ & (6.56) & (5.29) & (6.74) & (9.75)\end{array}$

Value of Land (Farm Value / Total Acres)

$\begin{array}{lcccc}\text { Shakers } & 43.1 & 39.8 & 49.6 & 60.3 \\ \text { Others } & 40.6 & 46.7 & 69.6 & 60.6 \\ & (0.25) & (0.97) & (1.21) & (0.02)\end{array}$

Capital (\$)

$\begin{array}{lcccc}\text { Shakers } & 29998.4 & 38228.7 & 62155.0 & 52409.9 \\ \text { Others } & 5237.1 & 5262.0 & 6951.0 & 5228.4 \\ & (9.00) & (8.99) & (5.77) & (10.58)\end{array}$

Capital / (Improved) Land Ratio (\$ / Improved Acres)

$\begin{array}{lcccc}\text { Shakers } & 78.9 & 89.2 & 94.1 & 115.5 \\ \text { Others } & 59.1 & 72.2 & 82.5 & 88.5 \\ & (1.76) & (1.52) & (0.37) & (1.60)\end{array}$

Number of Products

$\begin{array}{lcccc}\text { Shakers } & 13.2 & 13.0 & 11.9 & 12.2 \\ \text { Others } & 8.9 & 8.8 & 7.7 & 7.6 \\ & (8.81) & (9.20) & (6.23) & (8.10)\end{array}$

Ratio of Perishables

$\begin{array}{lcccc}\text { Shakers } & 0.32 & 0.31 & 0.20 & 0.27 \\ \text { Others } & 0.13 & 0.15 & 0.12 & 0.22 \\ & (6.99) & (5.65) & (2.51) & (1.44)\end{array}$

Notes: Figures in parentheses are the $\boldsymbol{t}$-statistics that test for the difference between the two means.

Source: U.S. Bureau of the Census, Enumeration Schedules of the Agriculture and Manufacturing Censuses, 1850- 
1880. 
TABLE 3

Determinants of Agricultural Productivity

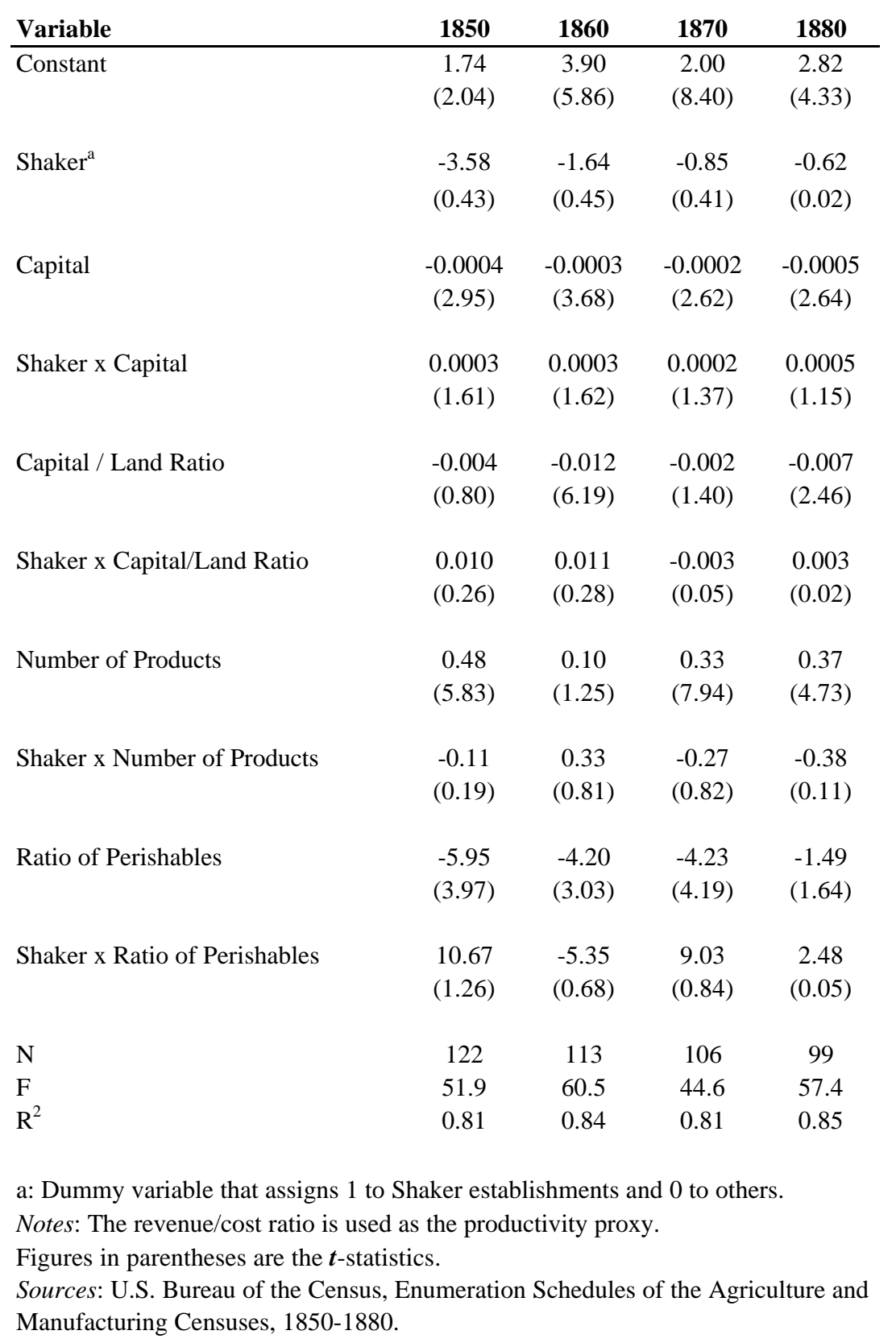




\section{REFERENCES}

- Andrews, Edward Deming (1963), The People Called Shakers. New York: Dover Publications.

- Andrews Edward D. and Faith Andrews (1974), Work and Worship: The Economic Order of the Shakers. Greenwich, CT: New York Graphic Society.

- Atack, Jeremy (1985), Estimation of Economies of Scale in Nineteenth Century United States Manufacturing. New York: Garland Publishing.

- Atack, Jeremy and Fred Bateman (1987), To Their Own Soil: Agriculture in the Antebellum North. Ames, IA: Iowa State University Press.

- Bainbridge, William Sims (1982), "Shaker Demographics 1840-1900: An Example of the Use of U. S. Census Enumeration Schedules." Journal for the Scientific Study of Religion 21: 352-365.

- Barkai, Haim (1977), Growth Patterns of the Kibbutz Economy. Amsterdam: North Holland.

- Bateman, Fred and Thomas Weiss (1981), A Deplorable Scarcity: The Failure of Industrialization in the Slave Economy. Chapel Hill: The University of North Carolina Press.

- Berry, Thomas S. (1943), Western Prices Before 1861. Cambridge, MA: Harvard University Press.

- Bonin, John P. and Putterman, Louis (1986), Economics of Cooperation and the LaborManaged Economy. New York: Harwood Academic Publishers.

- Bonin, John P., Jones, Derek C., and Putterman, Louis (1993), "Theoretical and Empirical Studies of Producer Cooperatives: Will the Twain Ever Meet?" Journal of Economic Literature 31: 1290-1320.

- Brewer, Priscilla J. (1986), Shaker Communities, Shaker Lives. Hanover: University Press of New England.

- Coşgel, Metin M., Thomas J. Miceli, and John E. Murray (1997), "Organization and Distributional Equality in a Network of Communes: The Shakers," American Journal of Economics and Sociology 56(2): 129-44.

- Ely, Richard T. (1886), The Labor Movement in America. New York: Thomas Y. Crowell.

- Gooden, Rosemary D. (1983), "A Preliminary Examination of the Shaker Attitudes toward Work," Communal Societies 3:1-15.

- Homer, Sidney and Richard Sylla (1991), A History of Interest Rates (1st edn., 1963) 3rd edn., New Brunswick, NJ: Rutgers University Press.

- Kandel, Eugene and Edward P. Lazear (1992), "Peer Pressure and Partnerships," Journal of Political Economy 100(4): 801-17.

- Keohane, Robert and Elinor Ostrom, eds. (1995), Local Commons and Global Interdependence: Heterogeneity and Cooperation in Two Domains. London: Sage Publications.

- Murray, John E. (1995), "Human Capital in Religious Communes: Literacy and Selection among Nineteenth Century Shakers." Explorations in Economic History 32: 217-35.

- Nordhoff, Charles (1875), The Communistic Societies of the United States from Personal Visit and Observation. New York: Harper and Brothers.

- Ostrom, Elinor (1990), Governing the Commons: the Evolution of Institutions for Collective Action. New York: Cambridge University Press. 
- Putterman, Louis (1983), "Incentives and the Kibbutz: Toward an Economics of Communal Work Motivation," Zeitschrift für Nationalökonomie [Journal of Economics] 43(2): 157-88.

- Putterman, Louis (1990), "Effort, Productivity, and Incentives in a 1970s Chinese People's Commune," Journal of Comparative Economics 14: 88-104.

- Roehl, Richard (1972), "Plan and Reality in a Medieval Monastic Economy: The Cictercians," Studies in Medieval and Renaissance History 9: 83-114.

- Ronk, S. E. (1936), "Prices of Farm Products in New York State, 1841 to 1935," Cornell University Agricultural Experiment Station Bulletin 643 (Mar. 1936)

- Sen, Amartya (1966), "Labor Allocation in a Cooperative Enterprise," Review of Economic Studies 33: 361-71.

- Stein, Stephen J. (1992), The Shaker Experience in America: A History of the United Society of Believers. New Haven: Yale University Press.

- U. S. Bureau of the Census, Enumeration Schedules of the Agriculture and Population Schedules (microfilm, 1850-1880).

- Weitzman, Martin and Douglas Kruse (1990), "Profit Sharing and Productivity," in Alan Blinder, editor, Paying for productivity: A look at the Evidence. Washington, DC:

Brookings. 